\title{
Guillain Barré Syndrome: A Rare Neurological Manifestation of COVID-19
}

\author{
Guillain Barré Sendromu: COVID-19’un Nadir Görülen Nörolojik Bir Tezahürü
}

Amina Chentouf

Oran 1 University, ACCIPED Laboratory, Department of Medicine, Es Senia, Algeria

Keywords: COVID-19, Guillain Barré syndrome, Algeria

Anahtar Kelimeler: COVID-19, Guillain Barré sendromu, Cezayir

\section{Dear Editor,}

I read with great interest the recently published journal article in issue 26 (2020) entitled: Coronavirus disease-2019 (COVID-19) and Neurology. This is a very interesting article that raised relevant issues, like COVID-19 diagnostic difficulties in the presence of isolated neurological manifestations, the impact of both neurological risk factors on the prognosis of COVID-19 victims as well as the COVID-19 pandemic on the management of neurological disorders.

In addition, the authors reported the most common severe acute respiratory syndrome coronavirus-2 (SARS-CoV-2) related neurological symptoms which included anosmia, ageusia, headache, nausea, vomiting, dizziness, sleep and visual disturbances, myalgia, seizures and stroke. Through this letter to the editor, we report another rare neurological manifestation of COVID-19: Guillain Barré syndrome.

Mrs. A.S, aged 31, presented to the neurological emergency department of the Oran University Hospital for muscle weakness accompanied by lower limb paresthesias evolving for 3 days, accompanied by facial asymmetry. Interrogation revealed a history of flu-like illness, a week earlier. Neurological examination revealed a predominantly areflexic flaccid tetraparesis in the lower limbs, a remarkable facial diplegia on the right as well as distal tactile hypesthesia. Dysautonomic signs were also noted (tachycardia at 143 beats/minute and arterial hypotension at $80 / 40 \mathrm{mmHg}$ ). Further paraclinical examinations were in line with the Guillain Barré syndrome. In fact, electroneuromyography (ENMG) demonstrated segmental demyelination without axonal damage (diminished conduction velocity, conduction blocks, prolongation of proximal
$\mathrm{F}$ and $\mathrm{H}$ latencies as well as distal latencies). Furthermore, analysis of the cerebrospinal fluid revealed albuminocytologic dissociation (proteinorachia: $1.36 \mathrm{~g} / \mathrm{l}$ and less than 5 lymphocytes $/ \mathrm{mm}^{3}$ ). The rest of the biological assessment [glycemia, blood count formula, sedimentation rate, C-reactive protein, hemostasis and renal assessment, serum protein electrophoresis, serology (Lyme, HIV, hepatitis A, B, and C, EBV, TPHA- VDRL), and immunological workupł were unremarkable. Given the context of the COVID-19 pandemic, SARS-CoV-2 infection was suspected and a nasal swab examination was performed. Polymerase chain reaction (PCR) analysis confirmed the diagnosis of COVID-19. The initial serology was negative in the absence of antibodies until 14 days post the onset of symptoms. The chest scan was normal. The patient received a 5 day immunoglobulin as well physiotherapy resulting in a 10-day improvement course.

To date, very few cases of Guillain Barré syndrome associated with COVID-19 have been reported in China, Italy, the United States, and Iran. Hua et al. (1) reported the first case of Guillain Barré syndrome in a 61-year-old woman who had traveled to Wuhan. She presented acute flaccid paraparesis associated to intense fatigue accompanied by a respiratory distress. The ENMG confirmed the diagnosis of Guillain Barré syndrome and the COVID-19 PCR was positive. The symptoms subsided after the administration of intravenous immunoglobulin and antiviral medications.

In Italy, Toscano et al. (2) reported five cases of COVID-19 with Guillain Barré syndrome confirmed by ENMG and managed with immunoglobulins or plasmapheresis. In the United States, Virani et al. (3) reported a case of Guillain Barré syndrome in a

Address for Correspondence/Yazışma Adresi: Amina Chentouf Prof. MD, Oran 1 University, Department of Medicine, Es Senia, Algeria Phone: 00213554650521 E-mail: amina.chentouf@yahoo.com ORCID: orcid.org/0000-0002-6004-019X

Received/Geliş Tarihi: 16.11.2020 Accepted/Kabul Tarihi: 08.11.2021

${ }^{\circ}$ Copyright 2021 by Turkish Neurological Society

Turkish Journal of Neurology published by Galenos Publishing House. 
54-year-old man who presented with diarrhea followed by rapid onset flaccid, areflexic, and ascending tetraparesis with respiratory distress. The COVID-19 PCR test was positive. The treatment outcome was favorable following administration of intravenous immunoglobulins and hydroxychloroquine. In Iran, Sedaghat and Karimi (4) reported the case of a 61-year-old man with COVID-19 who presented with subacute ascending quadriplegia with bilateral facial palsy. The ENMG study revealed axonal sensorymotor polyneuropathy.

In view of these few observations reported globally, we suggest the consideration of Guillain Barré syndrome as a neurological complication of COVID-19. Further large-scale studies are highly recommended to prove the cause-and-effect relationship between COVID-19 and Guillain Barré syndrome.

\section{Ethics}

Informed Consent: Informed consent was obtained.

Peer-review: Externally and internally peer-reviewed.

Financial Disclosure: The author declared that this study received no financial support.

\section{References}

1. Hua Z, Dingding S, Haiyan Z, Jun L, Sheng C. Guillain-Barré syndrome associated with SARS-CoV-2 infection: causality or coincidence?. Lancet Neurol 2020;19:383-384.

2. Toscano G, Palmerini F, Ravaglia S, et al. Guillain-Barré Syndrome Associated with SARS-CoV-2. N Engl J Med 2020;382:2574-2576.

3. Virani A, Rabold E, Hanson T, et al. Guillain-Barré Syndrome associated with SARS-CoV-2 infection. IDCases 2020;20:e00771.

4. Sedaghat Z, Karimi N. Guillain Barre syndrome associated with COVID-19 infection: a case report. J Clin Neurosci 2020;76:233-235. 